\title{
An Examination on the Knowledge Level of Breast Self- Examination of the Patients Who Apply to a University Hospital
}

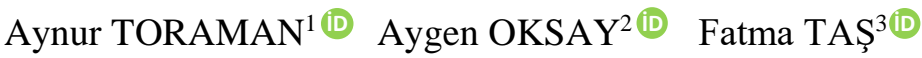

Submission Date: $12^{\text {th }}$ of March, 2019 Acceptance Date: $30^{\text {th }}$ of April, 2019 Pub.Date:29 ${ }^{\text {th }}$ of August, 2019

\begin{abstract}
Objective: The main aim of this study is to examine the knowledge level of women on breast cancer and breast self-examination who apply to the University Hospital's Obstetrics and Gynecology and General Surgery polyclinics. This study was made in accordance with the Declaration of Helsinki and this study supports the adoption of these principles by other people involved in medical research on human volunteers. Materials and Methods: The universe is formed by the patients that have applied to the University Hospital's Obstetrics and Gynecology and General Surgery polyclinics within the dates of June-July 2016. Within this study data was collected by the Champion's Health Belief Model Scales (CHBMS) and a total of 351 participants were reached.

Results: The $43.6 \%$ of the sample consists of women of $20-29$ ages, $71 \%$ of them are married and $27.4 \%$ of them have either an undergraduate or a post graduate degree. The perceived benefits concept has the most mean out of the 6 concepts in CHBMS. The study also showed that although $79.2 \%$ of the participants didn't have a breast problem; $27.6 \%$ of them said that they would do breast self-examine 3-4 times in a year.

Conclusion: As a result we can say that the participants are aware of the importance of breast selfexamination and that they have learned it from health professionals.
\end{abstract}

Keywords: Breast cancer, breast self-examination, patients.

\footnotetext{
${ }^{1}$ Dr. Öğr. Üyesi Aynur Toraman (Corresponding Author): Süleyman Demirel University, Faculty of Economics And Administrative Sciences, Department of Health Management, Isparta. +90 2422110694 e-mail: atoraman@yahoo.com

2 Doç. Dr. Aygen Oksay, Süleyman Demirel University, Faculty of Economıcs And Admınıstratıve Sciences, Department of Business Administration, Isparta. +90 $242 \quad 21100403$ e-mail: aygenoksay@sdu.edu.tr

3 Öğr.Gör. Fatma Taş, Mehmet Akif University, Gölhisar Vocational School of Health Services, Burdur. +90248 21374 00, e-mail:fatmatas27@gmail.com
} 


\title{
Üniversite Hastanesine Başvuran Hastaların Kendi Kendine Meme Muayenesi Hakkındaki Bilgi Düzeylerinin Araştırılması
}

\author{
Aynur TORAMAN ${ }^{1(\mathbb{D})}$ Aygen OKSAY (iD) Fatma TAŞ $^{3}$ (iD)
}

\section{Öz}

Amaç: Bu çalışmanın amacı Üniversite Hastanesi Kadın Doğum ve Genel Cerrahi polikliniklerine başvuran kadın hastaların meme kanseri ve kendi kendine meme muayenesi hakkındaki bilgi düzeylerini incelemektir. Bu inceleme Helsinki Bildirgesi’ne uygun olarak yapılmış olup, insan gönüllüler üzerinde yapılan tıbbi araştırmalara katılan diğer kişilerin de bu ilkeleri benimsemesini desteklemektedir.

Gereç ve Yöntem: Araştırmanın evrenini Haziran-Temmuz 2016 tarihleri arasında bir üniversite hastanesinin Kadın Doğum ve Genel Cerrahi polikliniklerine başvuran hastalar oluşturmaktadır. Bu çalışma kapsamında Champion Sağlık İnanç Modeli Ölçeği (CSİMÖ) kullanılarak 351 hastaya ulaşılmış ve elde edilen veriler SPSS15.0 ile değerlendirilmiştir.

Bulgular: Örneklemin \%43,6’sı 20-29 yaş arası kadınlardan oluşmakta; \%71'i evli ve \%27,4'ü lisans ve lisansüstü mezunudur. 6 boyuttan oluşan CSIMÖ’de en yüksek ortalamaya sahip boyutun yarar algısı boyutu olduğu görülmüştür. Ayrıca katılımcıların \% 79,2'si meme ile ilgili herhangi bir problem yaşamadıklarını ancak buna karşın \%27,6'sı yılda 3-4 kere kendi kendine meme muayenesi (KKMM) yaptıklarını belirtmişlerdir.

Sonuç: Katılımcıların KKMM'nin öneminin farkında olduğunu ve bu konu hakkındaki bilgiyi sağlık personelinden öğrendiğini söylemek mümkündür.

Anahtar sözcükler: Meme kanseri, kendi kendine meme muayenesi, hasta.

\footnotetext{
${ }^{1}$ Dr. Öğr. Üyesi Aynur Toraman (Sorumlu Yazar): Süleyman Demirel Üniversitesi, İktisadi ve İdari Bilimler Fakültesi, Sağlık Yönetimi Bölümü, Isparta. +90 242 2110694. e-posta: atoraman@ yahoo.com

2 Doç. Dr. Aygen Oksay, Süleyman Demirel Üniversitesi İktisadi ve İdari Bilimler Fakültesi, İşletme Bölümü, Isparta. +90 24221100403 e-posta: aygenoksay@sdu.edu.tr

3 Öğr.Gör. Fatma Taş, Mehmet Akif Üniversitesi, Gölhisar Sağlık Hizmetleri Meslek Yüksek Okulu, Tıbbi Dokümantasyon ve Sekreterlik Bölümü Burdur. +90 24821374 00, eposta:fatmatas27@gmail.com
} 


\section{Introduction}

Breast cancer provokes serious anxiety, even in healthy women, because it is both a frequent occurrence and a fatal disease. The three most common types of cancer in women are breast, colon and lung cancer worldwide. In Turkey the most common cancers are breast, thyroid and colorectal cancers. As a matter of fact, approximately 715,000 ( $26.5 \%$ of the total) in developed countries and 577,000 breast cancer cases $(18.8 \%)$ in underdeveloped countries are seen in a year. Breast cancer takes second place in incidence and mortality rates, followed by Kaposi's sarcoma and liver cancer The average incidence of breast cancer in the world is 38-40 per hundred thousand; 66-67 per hundred thousand in Europe and around 45 per hundred thousand in Turkey (THSK, Kanser Daire Bşk, 2016). The cancer with the highest prevalence in the world is breast cancer and the probability of developing breast cancer during life time in a woman in the United States is $12.5 \%$. The probability of death from breast cancer was calculated as $3.4 \%$ (Haydaroğlu, et.al. 2005).

The recognition of breast cancer at an early stage without complaints increases the likelihood that the disease will be completely treated. According to Cancer Facts \& Figures 2014, 61\% of breast cancer diagnoses can be detected early and 5-year survival expectation of the patients in the early period is $99 \%$ (Cancer Facts \& Figures, 2014). The first important step towards breast cancer is that women must have knowledge of and be aware of how to protect themselves from this disease. Early recognition of breast cancer is facilitated by the patient's sensitivity to this condition and the continuity of physicianpatient communication.

Generally, the first symptom of breast cancer is a palpable mass in the armpit or malformations that occur in the breast. The ability to detect such masses by the patient depends on the habit of periodic self-examining of the women. Unfortunately, the vast majority of women do not have enough knowledge on this issue. This is why they can't BSE (breast self-examination). The easiest way to overcome this problem is to give women the habit of asking themselves some questions during their lifetime (NTV, 2016).

For nearly sixty years, BSE has been introduced as an application that assures the lives of women who need early diagnosis of breast cancer and has been included in breast cancer screening guidelines by breast health authorities. It is a fact that BSE is important in the life of women in the early diagnosis of breast cancer due to its being economic, 
easy and able to be performed easily by women themselves (Akyolcu and Uğraş, 2011). The emergence of the first symptoms of breast cancer usually with a palpable mass reveals the importance of BSE for finding a mass in the breast. However the 2013 Research Report on Health Promotion in Turkey shows that only 5.4\% of women regularly do BSE every 2-3 months (See Table 1).

Table1. The Research on Women Doing BSE

\begin{tabular}{lc}
\hline \multicolumn{1}{c}{ EXPRESSIONS } & \% \\
\hline I have never done BSE so far. & 65,1 \\
\hline I occasionally ( less than 3 month) do BSE & 19,4 \\
\hline I regularly do BSE every month. & 10,1 \\
\hline I do BSE every 2-3 month. & 5,4
\end{tabular}

Resource: Research Report on Improving Health in Turkey, 2013.

A woman's application of BSE can be regarded as an initial behavior when applying to professionals and other precise diagnostic methods in the presence of a suspicious mass. On the other hand, a woman who regularly performs BSE every month may be more sensitive to definitive diagnostic methods, such as mammography and clinical breast examination. In this sense, a woman's performing BSE every month has a vital importance. Nevertheless, in studies conducted in Turkey, it has been determined that the vast majority of women do not perform BSE (Gözüm, Karyurt and Aydın, 2004). Breast ultrasonography, mammography and clinical breast examination methods, which are used other than BSE in the early diagnosis of breast cancer, are more definite diagnostic methods, but the implementation and evaluation of these methods requires the presence of a suspicious condition or routine controls over the age of 40 and the evaluation of a specialist physician (Kalichman, Williams and Nachimson, 2000). There are three main factors in breast cancer screening; self-examination of the breast, physical examination and mammography performed by the doctor (Kozan ve Tokgöz, 2016).

Cognitive-behavioral models have been developed in regulating and attaining health behaviors such as BSE and mammography screening for breast cancer screening. The first and the most used of these models is the Health Belief Model (HBM) There are six aspects defined in the HBM regarding beliefs and behaviors. These refer to: (a) sensory perception, a healthy person's perception of a probable danger; (b) the perception of severity/caring, the pernicious consequences of the threatening state on the 
person and the pernicious consequences of the threatening state; (c) benefit perception, perceived positive aspects of the occurrence of protective behavior; (d) obstacle perception, perceived negative aspects of the occurrence of protective behavior; (e) health motivation, general intent and desire for the development of behaviors in the maintenance and improvement of health; (f) confidence (self-efficacy), individual competence in implementing a health behavior (Gözüm et al., 2004).

Early diagnosis is very important in all types of cancer. In the community, awareness should be increased to ensure early diagnosis in breast cancer. The aim of this study is to contribute to this awareness. Another aim of determining the awareness levels of patients who applied to the university hospital.

\section{Methods and Materials}

The population is formed by the patients that have applied to the clinics of Obstetrics and Gynecology and General Surgery of the University Hospital within the dates of June-July 2016. The total number of patients applied to these two polyclinics on these dates is 4000 . The sample size to be reached at $95 \%$ significance level was calculated as 351. Convenience random sampling method was applied and the candidates were informed about the purpose of the research and how to participate in the research.

Since the survey data were wide-ranging and reliable, they were collected using the Champion Health Belief Model Scale (CHBMS). The scale consists of 42 questions and participants were asked to select the most appropriate option from the range of ' $1-\mathrm{I}$ never agree' and '5-I fully agree'. Participants were also asked for demographic information such as age, education, level of income and marital status.

The CHBMS scale consists of 6 aspects: sensory perception (1-3), the perception of severity/significance (4-10), benefit perception (11-14), obstacle perception (15-25), confidence/self-efficacy (26-35) and health motivation (36-42). Increasing scores on the scale means increasing sensitivity and caring, benefits for benefit perception, obstacles for obstacle perception, health motivation for health motivation, and self-efficacy for selfefficacy. The ones who agreed to participate in the study were first informed about the method of BSE by researchers themselves and tried to create awareness. During the lecture a standard application was carried out. The participants were explained in detail what the BSE is, why it is important and how it should be applied correctly. This is 
because correct and regular BSE is a simple and economic method protecting women's privacy in the early diagnosis of breast cancer. This narrative is also thought to have contributed significantly to the study because it would increase the awareness of women about breast cancer.

The data were analyzed with the SPSS 15.0 program with a 95\% significance level and $5 \%$ acceptable error rate. In order to decide which tests should be used to test hypotheses, the reliability of the data set was first measured and whether the data set exhibited normal distribution was checked.

\section{Findings}

Reliability analysis was first performed on the Champion Health Belief Model Scale (CHBMS) to determine which analyzes should be performed on the data. The Cronbach's alpha value of the scale was found to be 0.776 . If Cronbach's alpha values are between 0.60-0.80, then the scale is considered to be very reliable (Özdamar, 1999). It is possible to say that the scale applied in this case is quite reliable.

The demographic data is shown in detail in Table 2.

Table 2. Demographic Data

\begin{tabular}{|c|c|c|c|}
\hline & Demographics & $\mathbf{N}$ & $\%$ \\
\hline \multirow{6}{*}{ Age } & 19 age and below & 21 & 6,0 \\
\hline & $20-29$ & 153 & 43,6 \\
\hline & $30-39$ & 76 & 21,7 \\
\hline & $40-49$ & 62 & 17,7 \\
\hline & 50 and older & 39 & 11,0 \\
\hline & Total & 351 & 100,0 \\
\hline \multirow{3}{*}{ Marital Status } & Married & 250 & 71,2 \\
\hline & Single & 101 & 28,8 \\
\hline & Total & 351 & 100,0 \\
\hline \multirow{7}{*}{$\begin{array}{l}\text { Educational } \\
\text { Level }\end{array}$} & İlliterate & 3 & 0,9 \\
\hline & Primary School & 77 & 21,9 \\
\hline & Middle School & 46 & 13,1 \\
\hline & High School & 83 & 23,6 \\
\hline & Associate Degree & 46 & 13,1 \\
\hline & Undergraduate and Postgraduate & 96 & 27,4 \\
\hline & Total & 351 & 100,0 \\
\hline
\end{tabular}

As seen in Table 2, the $43.6 \%$ of the participants are between the ages of 20-29, $71 \%$ of them are married and $27.4 \%$ of them are either undergraduate or postgraduates. 
The average values of the 6 aspects of CHBMS were calculated and the results are shown in Table 3. These values show how much influence the aspects have on the participants.

Table 3. The Average Values of The Aspects of CHBMS

\begin{tabular}{lccc}
\hline Aspects & $\begin{array}{c}\text { Number of } \\
\text { Expressions }\end{array}$ & N & Mean \\
\hline Benefit perception & 4 & 333 & 4,0210 \\
Health motivation & 7 & 330 & 3,8237 \\
Severity perception & 7 & 329 & 3,1989 \\
Self-efficacy & 10 & 301 & 3,1691 \\
Susceptibility perception & 3 & 346 & 2,7466 \\
Obstacle perception & 11 & 302 & 2,3546 \\
\hline
\end{tabular}

As can be seen from Table 3, the aspect with the highest mean is the aspect of "benefit perception." This aspect essentially demonstrates the extent to which participants are aware of the benefits that the BCCM has provided to them. In fact, in this aspect, expression like 'Doing breast self-examination each month helps me to find breast masses early,' 'Every month doing breast self-examinations can reduce my chances of dying from breast cancer,' and 'When I perform a breast self-examination, if I detect an early mass, breast cancer treatment may not be bad.' are present. The average of this aspect is 4.02 , which clearly shows how well participants understand the importance of BSE.

The aspect with the lowest average is the "obstacle perception" aspect. The number of expressions in this aspect is more than all other aspects. Some of the expressions in the aspect are 'Breast self-examination is embarrassing me,' 'Breast selfexamination takes a lot of my time,' 'I forget to perform breast self-examination,' 'I do not have a place that protects my own privacy to perform breast self-examination.' As can be seen from these expressions, the obstacle perception aspect reveals the reasons why participants can't perform the BSE. A low average size in this aspect is mainly a positive result, indicating that there is no obstacle to the participation of the participants in the BSE.

When the responses of the participants to the questions related to the BSE were examined, it was seen that the vast majority (79.2\%) of the participants were not experiencing any breast problems and $49.3 \%$ of the participants were informed about the BSE by health personnel (Table 4). 
Table 4. The Rate of Having a Problem and Knowledge Acquisition About Breast Cancer of the Participants

\begin{tabular}{|c|c|c|}
\hline Questions & $\mathbf{N}$ & $\%$ \\
\hline \multicolumn{3}{|c|}{ Have you ever had a problem with breast cancer? } \\
\hline I haven't had. & 278 & 79,2 \\
\hline I have had. & 73 & 20,8 \\
\hline \multicolumn{3}{|c|}{$\begin{array}{l}\text { Is there anybody in your family who lived a problem with } \\
\text { breast cancer? }\end{array}$} \\
\hline No. & 277 & 79,1 \\
\hline Yes. & 73 & 20,9 \\
\hline \multicolumn{3}{|c|}{ How did you get information about BSE? } \\
\hline Health professionals & 171 & 49,3 \\
\hline Press & 100 & 28,8 \\
\hline No information & 76 & 21,9 \\
\hline
\end{tabular}

$32.5 \%$ of the participants did not give an answer to the question of how often they applied BSE in the last 1 year; only 27.6\% stated that they had done the BSE 3-4 times a year (Table 5).

Table 5. Participants' Status of Implementation BSE in The Recent Year

\begin{tabular}{lcc}
\hline $\begin{array}{l}\text { Status of Implementation BSE in the } \\
\text { Recent Year }\end{array}$ & N & \% \\
\hline Monthly & 83 & 23,6 \\
Every two months & 57 & 16,2 \\
3-4 times a year & 97 & 27,6 \\
No answer & 114 & 32,6 \\
\hline Total & $\mathbf{3 5 1}$ & $\mathbf{1 0 0 , 0}$ \\
\hline
\end{tabular}

\section{Discussions and Results}

In the majority of the studies conducted in our country, it was determined that the rate of women having knowledge and education about BSE is lower than the studies conducted abroad. It can be argued that this situation arises from the level of accessing 
and benefiting from educational resources (Duran, 2008). As a matter of fact, in the studies carried out on nurses, it has been observed that while monthly regular application rates of BSEs of nurses vary between $6 \%$ and $67 \%$ abroad; this ratio varies between $15 \%$ and 29\% at home (Karayurt, Cokun, Cerit, 2008). In a study by Secgili and Nahcivan (2006), it was found that the level of income of women, the presence of health-care providers and the knowledge of breast cancer affected the implementation of BSE. In the same study it was determined that there was no relationship between having breast cancer in the family and their marital status and BSE practice (Seçgili and Nevcihan, 2006). Similarly, Altunkan and colleagues found in the study of BSE awareness of women between 20-60 years of age that only $35.7 \%$ of those who had breast cancer stories in their families and $12.6 \%$ of those who did not have breast cancer stories in their families applied BSE once in a while (Altunkan et al., 2008).

As a result of a survey K1lıç and his colleagues conducted on university students, only $19.5 \%$ of them were found to have done BSE (Kılıç, Sağlam, Kara, 2009). In a study on nursing undergraduate students, when examined the condition of performing BSE at class level, only 1 student (1.9\%) in the first class, 26 students $(42.6 \%)$ in the second class and 18 students (32.1\%) in the third class and 25 students $(45.5 \%)$ in the fourth grade stated that they regularly applied BSE (Uzun, Karabulut, Karaman, 2004). It was determined in a study conducted in the US that $35.4 \%$ of women living in San Diego and $34.6 \%$ living in Phoenix perform BSE once a month (Coe et al., 1994). In another survey it was reported that $60.2 \%$ of the women in the Leningrand region do BSE (Semiglazov et al., 1992).

In the studies on the effect of education on BSE, it was indicated that $85 \%$ of the women had previously been trained in BSE but only $45 \%$ of the women had regular breast examination every month (Ersin and Bahar, 2012). According to the breast cancer screening protocol applied in our country in national cancer screening program, it is recommended that women between 20-40 years old should have a BSE per month and a clinical breast examination every two years. Women between 40 and 69 years of age are required to have a BSE per month, a clinical breast examination every year and a mammography every two years (THSK, Kanser Dairesi, 2016).

In the context of this study, it was found that $49 \%$ of participants were informed about the BSE by health personnel and $21.9 \%$ had no knowledge about it at all. One of 
the most important tasks for this issue is the training of breast cancer and early diagnosis methods for a group of healthcare personnel who have problems in health care. In a study conducted by Dündar and his colleagues, it was determined that $23.4 \%$ of the knowledge about the BSE was obtained from the health personnel and $39.3 \%$ from the radio / tv programs (Dündar et. al. 2006).

It is thought that education is the most appropriate tool that can be used to raise awareness. So much so that, in the study which Karayurt and his colleagues examined the impact of peer and group educations on knowledge and beliefs about breast cancer and BSE, knowledge and practice of BSE increased and perceived health beliefs developed after the education (Karayurt, Dicle and Tuna, 2009). In another study, it was determined that participants' perceptions of BSE and their confidence increased due to the education given to the mothers and their daughters (Gürsoy et al. 2009). Another study emphasizing the importance of education is the study Avcı and Gözüm conducted on preschool teachers. In this study participants were divided into two groups and it was found that their perceived self-esteem and sensitivity to breast cancer increased after training (Avc1 and Gözüm, 2009). In addition nurses/midwives who provide services within the scope of family practice can contribute to the women they are responsible for by giving training on BSE and making their examinations accurate and regular. Because BSE is a procedure which is simple, non-invasive, non-hazardous, requires no tools, can be performed in a short time and is at no cost (Kılıç, Sağlam and Kara, 2009). Due to the fact that the nurses who are part of the health team are in constant contact with women, great responsibilities fall on them about education. Nurses play an important role in teaching and disseminating $\mathrm{BSE}$ at centers and/or at home providing rehabilitation services such as hospitals, schools, health centers, cancer associations (Koca, 2010).

As in many studies, active training programs aimed at increasing women's awareness of breast cancer were found useful in this study. It can be stated that other important tools in society's awareness of cancer and cancer prevention are the Internet and media. In this context, the awareness of the people can be increased by the effective use of these tools.

The most important steps to be taken in reducing the risk of breast cancer are to manifest the risks of breast cancer in each community, identify risk groups and promote screening programs (Eti and Gürkan, 2007). All in all, early diagnosis of this disease 
minimizes the removal of breast completely (mastectomy), which is the biggest nightmare of women. For this reason diagnosis of the disease should be made as early as possible. From this point of view, the importance of BSE is even better understood.

The fact that it was made to patients who applied to university hospital constitutes the limitation of this study. Other constraints are the fact that the research is partially reflective of the area under investigation due to voluntary planning. 


\section{References}

Akyolcu N, Uğraş G., (2011). Kendi Kendine Meme Muayenesi: Erken Tanıda Ne Kadar Önemli. Meme Sağllğg Dergisi, Say1:7 s:10-14.

Altunkan H, Akın B, Ege E., (2008). 20-60 Yaş Arası Kadınların Kendi Kendine Meme Muayenesi Uygulama Davranışları ve Farkındalık Düzeyleri, Meme Sağlı̆̆ı Dergisi, 4: 84-91.

Avc1 Aİ, Gözüm S.(2009). Comparison of two different educational methods on teachers' knowledge, beliefs and behaviors regarding breast cancer screening. European Journal of Onkology Nursing, 13: 94-101. (PMID:19230770)

Canser Afacts\& Figures, American Cancer Society, 2014, (cited 19.04.2019). Available from: URL:https://www.cancer.org/content/dam/cancer-org/research/cancer-facts-andstatistics/annual-cancer-facts-and-figures/2014/cancer-facts-and-figures-2014.pdf

Coe K, Harmon MP, Castro EG, Campbel IN, Meyer JA, Meyer JP,(1994). Breast self examination: Knowledge and Practices of Hispanic women in two Southwestern Metropolitan Areas. J Community Health 19: 433-448. (PMID: 7844248)

Duran Ö., (2008). Kendi Kendine Meme Muayenesi İle İlgili Verilen Planlı Eğitimin Kadınların Sağlık İnançları ve Algılanan Sağlık Durumlarına Etkisi, Sağllk Bilimleri Enstitü Dergisi, Cumhuriyet Üniversitesi.

Dündar EP, Özmen D, Öztürk B, Haspolat G, Akyıldız F, Çoban S, Çakıroğlu G,(2006). The Knowledge And Attitudes Of Breast Self-Examination And Mammography in a Group Of Women in a Rural Area in Western Turkey. BioMedCentral Cancer, 6: 3-22.

Ersin B, Bahar Z,(2012). Sağlı̆̆ı Geliştirme Modelleri'nin Meme Kanseri Erken Tanı Davranışlarına Etkisi: Bir Literatür Derlemesi. Dokuz Eylül Üniversitesi Hemşirelik Fakültesi Elektronik Dergisi, 5: 28-38.

Eti AF ve Gürkan A.(2007). Kadınlarda Meme Kanseri Risk Düzeyi. Meme Sağllğg Dergisi, 3:6368.

Gözüm S, Karayurt Ö, Aydın İ., (2004). Meme Kanseri Taramalarında Champion'un Sağlık İnanç Modeli Ölçeğinin Türkçe Uyarlamalarına İlişkin Sonuçlar, Hemşirelikte Araștırma Geliștirme Dergisi, Sayı:1 s:71-85.

Gürsoy A, Yılmaz, F, Nural N, Kahriman İ, Yigitbaş Ç, Erdöl H, Kobya Bulut H, Yeşilçiçek K, Karadeniz MH, Hindistan S,(2009). A Different Approach to Breast Self-Examination Education: Daughters Educating Mothers Creates Positive Results in Turkey. Cancer Nursing, 32: 127-134.

Haydaroğlu A, Dubova S, Özsaran Z, Bölükbaşı Y, Yılmaz R, Kapkaç M, Özdedeli E., (2005). Ege Üniversitesinde Meme Kanserleri: 3897 Olgunun Değerlendirilmesi. Meme Sağllğ Dergisi, $S: 1 \mathrm{~s}: 6-11$.

Kalichman SC, Williams E, Nachimson D.,(2000). Randomized Community Trial Of A Breastself-Examination Skills-Building Intervention For Inner-City African-American Women, Journal of the American Medical Women Association, 55: 47-50. (PMID: 10680410)

Karayurt Ö, Coşkun A, Cerit K., (2008). Hemşirelerin Meme Kanseri ve Kendi Kendine Meme Muayenesine İlişkin İnançları ve Uygulama Durumu, Meme Sağlı̆̆ Dergisi, 4:15-20

Karayurt Ö, Dicle A, Tuna MA, (2009). Effects of Peer and Group Education on Knowledge, Beliefs and Breast Self-Examination Practice among University Students in Turkey. Tübitak Turk J Med Sci. 39: 59-66.

Kılıç D, Sağlam R, Kara Ö,(2009). Üniversite Öğrencilerinde Meme Kanseri Farkındalığını Etkileyen Faktörlerin İncelenmesi. Meme Sa ̆̆lı̆̆l Dergisi, S: 5:195-199.

Koca B.(2010). Kendi Kendine Meme Muayenesini Bilmenin Kadın Sağlı̆̆ Açısından Önemi. Yeni Tip Dergisi, 27: 10-14.

Kozan R., Tokgöz VY., (2016). Türkiye'de Meme Kanseri Farkındalığı ve Tarama Programı. ACU Sağlik Bil Dergisi, 4:185-188. 
NTV. (cited 13.07.2016). Available from: URL: http://www.ntvmsnbc.com/id/25140502/ \#storyContinued.

Özdamar K., (1999). Paket Programlar İle İstatistiksel Veri Analizi, Kaan Kitapevi, Eskişehir.

Seçgili S, Nahcivan N., (2006). Factors Associated With Breast Cancer Screening Behaviours In A Sample Of Turkish Women: A Questionnaire Survey, International Journal of Nursing Studies, 43: 161-171. (PMID: 16427965)

Semiglazov VF1, Moiseyenko VM, Bavli JL, Migmanova NSh, Seleznyov NK, Popova RT, Ivanova OA, Orlov AA, Chagunava OA, Barash NJ,(1992). The role of breast selfexamination in early breast cancer detection (results of the 5-years USSR/WHO randomized study in Leningrad). Eur J Epidemiol, 8: 498-502. (PMID: 1397215)

Türkiye Halk Sağlığı Kurumu Kanser Daire Başkanlığı. Kanser Raporu, 2016. Available from: http://www.onkoloji.gov.tr/attachments/article/8653/Ana\%20Rapor\%202016\%20(v01 .2).pdf

Uzun Ö, Karabulut N, Karaman Z,(2004). Hemşirelik Öğrencilerinin Kendi Kendine Meme Muayenesi İle İlgili Bilgi ve Uygulamaları. Atatürk Üniversitesi Hemşirelik Yüksekokulu Dergisi, Say1: 7: 10-19. 